\title{
Paleontological Resources at Grand Teton National Park, NORTHWESTERN WYOMING
}

\author{
VINCENT L. SANTUCCI $\downarrow$ NATIONAL PARK SERVICE \\ KEMMERER $\downarrow$ WY \\ WILLIAM P. WALL $\uparrow$ DEPARTMENT OF BIOLOGY \\ GEORGIA COLLEGE AND STATE UNIVERSITY \\ MILLEDGEVILLE $\downarrow$ GA
}

\begin{abstract}
$\uparrow \quad$ ABSTRACT
Paleontological resources occur throughout the formations exposed in Grand Teton National Park. A comprehensive paleontological survey has not been attempted previously at Grand Teton National Park. Preliminary paleontologic resource data is given in this report in order to establish baseline data.
\end{abstract}

\section{$\downarrow \quad$ INTRODUCTION}

The original Grand Teton National Park was established by Congress on February 29, 1929. (45 Stat., 1314). It was then expanded in 1950. The park now encompasses approximately 310,000 acres in northwestern Wyoming. Shallow seas transgressed and regressed over this area from 600 million years ago until 65 million years ago. These seas provided the sediments for the nearly 26,000 feet of sedimentary rock exposed in the park today. Many of these layers are fossiliferous. The Teton Range is the youngest mountain range in North America, formed by crustal extension only 5 to 9 million years ago. The Teton Fault is a normal fault that is still active today, with over 30,000 feet of vertical separation. Several periods of glaciation carved the dramatic landscape, and though the last great ice masses melted 15,000 years ago, some re-established small glaciers still exist.

This report provides a preliminary assessment of paleontological resources identified at Grand Teton National Park.

\section{$\downarrow$ STRATIGRAPHY}

The stratigraphic record at Grand Teton National Park extends from the Cambrian through the Tertiary. The only time period during this interval that is not represented is the Silurian. Brief descriptions of the stratigraphic units exposed at Grand Teton are provided below.

\section{Flathead Sandstone (Cambrian)}

This formation is exposed along the north and west flanks of the Teton Range, as well as the north and west flanks of the Gros Ventre Mountains. The Flathead Sandstone is partially marine. These marine sections are characterized by a red-brown, medium grained quartz arenite, some of which contain horizontal feeding traces and vertical burrows. 


\section{Gros Ventre Formation (Cambrian)}

The Gros Ventre Formation is exposed along the north and west flanks of the Teton Range and Gros Ventre Mountains. The formation is made up of about 700 feet greenish gray marine shale and limestone. The Death Canyon Member, a cliff building limestone, makes up 300 feet of this sequence. The plant fossil Tetonophycus blackwelderi was collected in the park near the head of Death Canyon in the Death Canyon Member of the formation.

\section{Gallatin Limestone (Cambrian)}

The Gallatin Limestone is exposed along the north and west flanks of the Teton Range and Gros Ventre mountains. This formation is a blue-gray thinbedded marine limestone that ranges from 200 to 300 feet in thickness. Three genera of conodonts, Preconodontus, Eoconodontus, and Cambrooistodus are reported from this formation.

\section{Bighorn Dolomite (Ordovician)}

The Bighorn Dolomite is exposed along the north and west flanks of the Teton Range, the north and west flanks of the Gros Ventre Mountains, and in southern Jackson Hole. This formation is a graywhite fine-grained marine dolostone that is between 300 and 500 feet thick. Several marine invertebrates including brachiopods, bryozoans, and corals are preserved in this formation.

\section{Darby Formation (Devonian)}

This formation is exposed along Darby Creek, the western slopes of the Teton Range, the north slopes of the Gros Ventre Mountains and southern Jackson Hole. It consists of sandy and silty gray-brown limestone, often interbedded with brown and green shales and siltstones. The Darby formation correlates with the Jefferson and Three Forks formations of Montana. The section on the western slope of Glory Mountain is 327 feet thick. The lower 151 feet of this section, which corresponds to the Jefferson Formation, contains rod-like organic structures, crinoid fragments, brachiopods, and ostracodes. The upper $176 \mathrm{feet}$, corresponding to the three Forks Formation, contain a crinoidal limestone in the lower part.

\section{Madison Limestone (Mississippian)}

The Madison Limestone is exposed on the north and west flanks of the Teton Range, the north slopes of the Gros Ventre Mountains and southern Jackson Hole. It is a blue-gray marine limestone that ranges from 1,000 to 1,200 feet thick in the Teton area. Though referred to as a fossiliferous unit, the outcrops within the park have not been surveyed for fossils, and there are no reports of fossils collected from this unit inside the park. Brachiopods and corals have been collected from this formation outside the park.

\section{Amsden Formation (Pennsylvanian)}

This formation is exposed on the north and west flanks of the Teton Range, the north slopes of the Gros Ventre Mountains and southern Jackson Hole. It consists of reddish marine dolostone and shale, and contains a basal red sandstone. The Amsden Formation is about 300 feet thick in this area. Poorly preserved fossil traces and much crinoid stem debris is reported from the formation.

\section{Tensleep Sandstone (Pennsylvanian)}

The Tensleep Sandstone, a light gray hard sandstone, is exposed on the north and west flanks of the Teton Range, the north flank of the Gros Ventre Mountains and southern Jackson Hole. The following fossils were collected in the park by J.D. Love, 1953: Climacammina sp., Bradyina sp., Textrataxis sp., Pseudotaffella or possibly Milleralla sp., Fusulina sp., and Prismopora sp.

\section{Phosphoria Formation (Permian)}

The Phosphoria Formation is exposed on the north and west flanks of the Teton Range, the north slopes of the Gros Ventre Mountains, and southern Jackson Hole. It is made up of marine beds of gray dolostone, black shale, and phosphate. The formation ranges from 150 to 250 feet in thickness. Sponge spicules are reported from this layer.

\section{Dinwoody Formation (Triassic)}

The Dinwoody Formation is exposed on the north end of the Teton Range, the north flank of the Gros Ventre Mountains, and southernmost Jackson Hole. It is a brown, thin-bedded, marine siltstone that ranges between 200 and 400 feet in thickness. Conodonts are reported from this layer.

\section{Chugwater Formation (Triassic)}

This formation is exposed on the north end of the Teton Range, the north flank of the Gros Ventre Mountains, and southernmost 
Jackson Hole. The Chugwater formation is made up of red, thin-bedded sandstone and shale with a thin bed of limestone near the top. It is between 1000 and 1500 feet thick.

The lowest member is known as the Red Peak. The two upper members are known as the Popo Agie and the Alcova. The Red Peak Member is predominantly siltstone and is not fossiliferous. The Alcova Limestone Member consists of a thin, hard, fine-bedded, pinkish to light-gray limestone. Fossils from the Alcova place it in Middle or Upper Triassic. The lower part of the Popo Agie member resembles the Red Peak member, and the top consists of an earthy, powdery, brown claystone overlying purple to red silty shales and limestone pellet conglomerates. This member does contain fossils.

\section{Nugget Sandstone (Triassic/Jurassic)}

This formation is exposed on the north flank of the Gros Ventre Mountains, Blacktail Butte and southern Jackson Hole. The Nugget Sandstone is a hard, red sandstone that ranges from nonexistent to 350 feet in the park area.

\section{Gypsum Spring Formation (Jurassic)}

This formation is exposed on the north end of the Teton Range, Blacktail Butte, and in the Gros Ventre River valley. The Gypsum Spring Formation is a partly marine white gypsum interbedded with shale and dolomite. It ranges from 75 to 100 feet thick in this area. The ammonites Stemmatoceras and Chondroceras are reported from this layer. Six pelecypod species were also collected from in and around the park.

\section{Sundance Formation (Jurassic)}

The Sundance Formation is exposed on the north end of the Teton Range, Blacktail Butte, and in the Gros Ventre River valley. The formation is between 500 and 700 feet thick. The lower unit is composed of marine gray shale and limestone. The limestone in this unit is highly fossiliferous, the most common fossils being clams, crinoids and belemnoids. The upper unit is a greenish sandstone. Dinosaur tracks and bones have been produced from this formation outside the park.

\section{Morrison Formation (Jurassic)}

This formation is exposed on the north end of the Teton Range and in the Gros Ventre River valley. The Morrison and Cloverly formations together are 650 feet thick in this area. It is a silty sandstone and claystone. No fossils have been found in this layer inside the park.

\section{Cloverly Formation (Early Cretaceous)}

The formation is exposed on the north end of the Teton Range and in the Gros Ventre River valley. In this area the Cloverly formation is a light gray sandstone with a rusty unit near the top. The Cloverly Formation has produced many dinosaur fossils in the Bighorn Basin, and Carbon County Montana, but fossils have not yet been reported from this formation in the Teton Range.

\section{Thermopolis Shale (Early Cretaceous)}

The Thermopolis Shale is exposed in the Gros Ventre River valley, along the northern boundary of the park, and in southern Jackson Hole. Ranging from 150 to 200 feet thick, it is a fissile, black, marine shale with sandstone at the top. Though plesiosaur bones have been excavated from this formation nearby, no fossils are reported in the park. An abundant fauna of foraminifers is reported from areas to the east of the park.

\section{Mowry Shale (Early Cretaceous)}

This formation is exposed in the Gros Ventre River valley, along the northern boundary of the park, and in southern Jackson Hole. The Mowry Shale is a gray-black marine shale that is 700 feet thick in this area. Three variants of the ammonite Neogastroplites cornutus (Whiteaves) were collected by Eliot Blackwelder. It also contains many fish scales, and fish teeth have been reported.

\section{Frontier Formation (Late Cretaceous)}

This formation is exposed in the eastern and northern parts of Jackson Hole, and at the southwestern margin of Jackson Hole. The Frontier Formation is made up of gray, marine sandstone and shale with some thin porcellanite beds, and is almost 1000 feet thick in the park. Foraminifera have been reported from this layer, and some of the shale layers are oyster-bearing. The following plant fossils have been identified in the porcellanite beds: Plantanus sp., Anemia fremonti, Gleichenia comptoniaefolia, Gleichenia nordenskioldi, Gleichenia cf. $G$. nauckhoffi, and Ficus fremonti. A sandstone bed near the middle of the formation contains a marine molluscan fauna. The ammonites Collgnoniceras woollgari (Mantell) var. intermedia, Placenticeras planum, and Peroniceras have been collected from 
that bed. The upper sandstone beds in the Frontier Formation contain Inoceramus deformis Meek and Ostrea sannionis White.

\section{Cody Shale (Late Cretaceous)}

The Cody Shale is exposed in the northern and eastern parts of Jackson Hole. It is composed of soft gray marine shale and thin-bedded green sandstone and ranges in thickness from 1300 to 2200 feet. This formation contains marine fossil mollusks and microfossils throughout. Inoceramus exogyroides, I. undabundus and Scaphites ventricosus (Meek and Hayden) were reported by W.A. Cobban. The following fossils were collected and identified on Blackrock Meadows by J.A. Cushman: Robulus pseudosecans (Cushman), $R$. munteri (Roemer), Nodosaria affinis (Reuss), $N$. distans (Reuss), Frondicularia inversa (Reuss), Vaginulina taylorana (Cushman), and Bullopora laevis (Sollas). The following ostracodes were collected at the same locality: Cytherella cf. $C$. kansasensis Morrow, Cytherella sp., Cytheridea cf. C. fabaformis Berry, Cythereis aff. C.paraustinensis Swain, Brachycythere cf. B. sphenoides (Reuss) and Orthonotacythere sp.

\section{Bacon Ridge Sandstone (Late Cretaceous)}

This formation is exposed in eastern Jackson Hole and along the eastern boundary of the park. The Bacon Ridge Sandstone is made up of light gray massive sandstone, gray shale, and numerous coal beds. It ranges from 900 to 1200 feet thick in this area. The sandstone contains large Inoceramus shells, shell fragments, and shell prisms. A volcanic tuff layer contains black leaf impressions of Trapa microphylla Lesquereux, and seeds.

Lenticular sandstone and shale sequence (Late Cretaceous)

This sequence is exposed in the southeastern part of Jackson Hole, south of Mount Leidy, and near the Bacon Creek and Fish Creek junction. The sequence is about 2,300 to 2,400 feet of nonmarine channel deposits of sandstone and shale. It contains an abundant and well preserved flora and some nonmarine mollusks.

\section{Mesa Verde Formation (Late Cretaceous)}

The Mesa Verde Formation is exposed along Spread Creek, on both flanks of the Spread Creek anticline, and on the northeast flank of the Bacon Ridge anticline. It varies greatly in thickness from
200 to nearly 1,000 feet. This formation is primarily massive, white, coarse-grained sandstone. Sparse nonmarine mollusks, chara oogonia, and a wellpreserved flora were found in the Dry Cottonwood Creek section.

\section{Meeteetse Formation (Late Cretaceous)}

This formation is made up of chalky tuffaceous sandstone, blue-gray siltstone, white tuff, carbonaceous claystone and shale, impure coal beds, and yellow-green bentonite beds. The Meeteetse Formation is 170 feet thick in Spread Creek Canyon where the formation is exposed. Many plant fossils (mostly individual leaves) are found in this formation. A tuffaceous sandstone yielded the following plant fossils: Asplenium sp., Equisetum sp., and Platanus sp.

\section{Harebell Formation (Late Cretaceous)}

The Harebell Formation crops out over 130 miles in the northeast corner of Teton County. It is made up of gray sandstone, conglomerate, claystone and shale, and is approximately 5,000 feet thick. The basal beds of sandstone, siltstone, claystone and shale contain leaves, invertebrates, and poorly preserved bone fragments.

\section{Pinyon Conglomerate (Paleocene)}

The Pinyon conglomerate is made up of two members, a lower coal member and an overlying conglomerate member.

The coal member is exposed in southern Jackson Hole and north of Mount Leidy and is 50 to 140 feet thick. It consists of black coaly shale, coal beds, gray claystone and thin lenticular sandstone beds. The only fossils in the coal member consist of small, very fragile mollusks. These were identified by T.C. Yen as Pisidium sp., Valvata sp., Velatella cf. $V$. baptista White, and Physa sp.

The conglomerate member is exposed along the southeast margin of Jackson Hole, along Fish Creek and Cottonwood Creek, in the Mount Leidy Highlands, and on the top of Gravel Mountain. It ranges from 1,000 to 1,500 feet in thickness and is composed entirely of smoothly rounded red, gray, black, and yellow pebbles, cobbles and boulders from pre-Cambrian quartzites and igneous rocks. Fossils are sparse in the conglomerate facies. The terrestrial gastropods Oreohelix megarche Cockerell and Henderson, and Grangerella sinclairi (Cockerell), 
identified by J.B. Reeside Jr. were collected from this layer.

Greenish-gray and brown sandstone and claystone sequence (Paleocene)

This sequence is exposed along both forks of Fish Creek, along Cottonwood Creek, and in southeastern Jackson Hole. There are between 1,000 and 2,000 feet of gray-brown sandstone, green-gray shale and claystone, and thin coal beds. The shale and claystone portion of the sequence contains numerous gastropods and a few pelecypods. The following freshwater mollusks were collected from the lower and middle part of the sequence on both forks of Fish Creek and on Cottonwood Creek (Love, 1947) and identified by T.C. Yen: Helicina $\mathrm{cf}$. H. evanstonensis (White), Viviparus cf. V.trochiformis (Meek and Hayden), Viviparus sp., Lioplacodes cf. $L$. limnaeiformis (M. \& H.), L. cf. L. mariana Yen, L. cf. L. tenuicarinata (M. \& H.), Lioplacodes sp., Aplexa cf. A. atava (White), Aplexa sp., Micropyrgus cf. M. minutulus (M. \& H.), Micropyrgus sp., Pleurolimnaea tenuicosta (M. \& H.), Valvata cf. $V$. subumbilicata (M. \& H.), Lymnaea sp., Gyraulus sp., Sphaerium sp., Pisidium sp., Eupera sp., Pseudocolumna sp., Unio cf. U. priscus M. \& H. In the same localities, the following plants were collected and identified by R.W. Brown: Taxodium occidentale Newberry, Cercidiphyllum arcticum (Heer) Brown, Vitis sp., Viburnum cf. V. antiquum (Newberry) Hollick, Aralia notata Lesquereux, Sapindus affinis Newberry, Cambomba gracilis Newberry.

\section{Wind River Formation (Eocene)}

The Wind River Formation is exposed along both forks of Fish Creek and south of Togwotee Pass. It is composed of claystone, coal, and sandstone beds. This formation is about 1,800 feet thick in this area. Both the coal and the overlying black shale and gray sandstone are fossiliferous with gastropods and pelecypods.

\section{Indian Meadows Formation (Eocene)}

This formation is exposed along the eastern margin of Jackson Hole, both forks of the Fish Creek, and south of Togwotee Pass. The Indian Meadows Formation consists of interbedded red clay, shale, sandstone, and conglomerate approximately $1000 \mathrm{ft}$ thick. The age of Eocene is based on vertebrate fossils found in the formation. The conglomerate is made up of nodules of Paleozoic granite, limestone, dolomite, and chert. There are also algal-ball limestone beds. These beds are made up primarily of rounded masses of limestone. The limestone is arranged in concentric layers around nuclei, which are commonly Goniobasis sp.

\section{Unnamed Rocks (Eocene)}

These rocks are exposed along Togwotee Pass, and are about 1,000 feet thick. These layers are made up of a quartzite pebble conglomerate, tuff, coarse-grained gray sandstone, green claystone, and thin bentonite beds. The sequence contains the following mollusks (identified by T.C. Yen): Oreohelix cf. O. magarche Cockerell and Henderson, Holospira cf. H. leidyi (Meek), Goniobasis cf. G. arcta (Meek), ?Goniobasis sp., Physa cf. P. pleromatis White, Lymnaea sp., Drepanotrema sp., Sphaerium sp., "Planorbis" sp., ?Viviparus sp., Pisidium sp. Thin beds of carbonaceous shale and claystone interbedded with the tuffs contain the following leaves: Lygodium kaulfussi Heer, Ficus wyomingana Lesquereux, Mimosites coloradensis Knowlton, Phyllites furcivena Brown, Platanus sp., Arala sp., Sassafras sp., Equisetum sp., Sparganium antiquum (Newberry) Berry. The white rhyolite tuffs contain these plants: Lygodium kaulfussi Heer, Dryopteris weedi Knowlton, Osmunda sp., Equisetum sp., ?Juglans or Sapindus sp., Lomatia coloradensis (Knowlton) Brown, ?Koelreuteria nigricans (Lesquereux) Brown, Plantus sp., Cinnamomum sp., and Mimosites sp.

\section{Wiggins Formation (Oligocene)}

The Wiggins Formation is exposed on the north flank of the Wind River Mountains and along Mink Creek. This formation is up to 2,000 feet thick in the area, and is composed of massive volcanic conglomerate and breccia with volcanic rock fragments as much as three feet in diameter interbedded with fine-grained tuffs. The unit is assigned an Oligocene age on the basis of vertebrate fossils. Also described another Oligocene vertebrate fauna from this formation near Mink Creek. Those fossils (identified by M. J. Hough) are: Cylindrodon cf. C. fontis, Ischyromys cf. I. parvidens, Megalagus brachyodon, Paleolagus temnodon, Eutypomys sp., Teleodus cf. T. umtensis, and Poebohterium sp.

\section{Colter Formation (Miocene)}

This formation is exposed near Pilgrim Peak, Two Ocean Lake, and in northeastern Jackson Hole. The Colter Formation is several thousand feet thick. It is made up of mixed tuffs containing shards, rock fragments, and minerals of mafic character. The 
following fossils were described from localities near Two Ocean Lake: Domninoides storeri, Oreolagus colteri, Hypolagus, species intermediate, Spermophilus primitivu, Tamias ateles, Petauristodon, species intermediate, Allomys cristabrevis, Monosaulax, cf. M. curtus, Perognathus furlongi, Cupidinimus sp., Diprionomys agrarius, Mojave magnumarcus, Schaubeumys, species intermediate, Parahippus tyleri, Merycochoerus proprius magnus, and ?Oxydactylus, species intermediate (Barnosky, 1986).

\section{Camp Davis Formation (Pliocene)}

The Camp Davis Formation is exposed in southeast Jackson Hole and is several thousand feet thick. The lower part consists of light gray conglomerate mostly limestone and dolomite. The middle section is pinkish limestone, claystone, tuff, pumicite, conglomerate, and diatomite. The upper part is red conglomerate made up of sandstone and siltstone from Triassic rocks. Tuffaceous sedimentary layers in this formation have produced a horse tooth, Pliohippus sp. Mollusks, ostracodes, and diatomite were collected by J.D. Love in 1956.

\section{Teewinot Formation (Pliocene)}

This formation is a thick succession of white limestone, tuff, pumicite, claystone and conglomerate. It is exposed on fault blocks in Jackson Hole and on the western flank of the Gros Ventre Mountains. The Teewinot Formation is at least 5,000 feet thick. Some of the claystone beds are almost coquinas of small mollusks and ostracodes. A bed 200 feet below the top of the section produced vertebrate fossils, mostly jaw fragments and teeth, they are Dipoides stirtoni and Goniodontomys disjunctus. One complete jaw of Blarina sp. was found. In the same layer the following mollusks were found (identified by Taylor in personal communication to Love, 1956): Psidium sp., Valvata humeralis (Say), Scalez sp., Lymnaea sp., L. aff. caperata Say, Vorticifex sp., Pupilla muscorum, Succinea cf. avara Say, S. cf. grosvenori Lea, Discus cronkhitei (Newcomb), Oreohelix cf. subrudis (Pfeiffer), Hawiia minuscula (Binney). Zannichellia sp., Potamogeton sp., Abies sp., coniferous wood, and a possible fragment of a pinecone were also identified by R.W. Brown. The ostracodes collected were Limnocythere sp., ?Ilyocypris sp., Lineocypris sp., ? Candona sp., and Cyprinotus sp. (Sohn, 1956). J.D. Love collected the following fossils from the Teewinot Formation near the Gros Ventre River in 1964 for Grand Teton National Park's museum collection: incisor of Dipoides stirtoni, pelvis of Dipoides stirtoni, and radius of Dipoides stirtoni.

\section{Bivouac Formation (Pliocene)}

The Bivouac formation is exposed on Signal Mountain. It is composed of conglomerate, welded tuff, and thin pumicite. It is brown-gray and poorly stratified. No fossils have been found in this formation.

\section{Quaternary deposits}

There are deposits of white ash, outwash, and fine-grained sand and silt. These deposits are scattered over numerous areas in and around the park. A laminated silt near Pilgrim Creek produced carbonized wood with a carbon 14 date of 27,100 years \pm 800 years. A white marl south of Signal Mountain contains abundant gastropods whose shell material was dated as 9,580 \pm 250 years and from a nearby locality as $8,800 \pm 250$ years (U.S.G.S. Lab. No. W-392 and 393).

\section{$\downarrow$ Literature Cited}

Barnosky, Anthony D., 1986. Arikareean, Hemmingfordian, and Barstovian Mammals from the Miocene Colter Formation, Jackson Hole, Teton County, Wyoming. Bulletin of Carnegie Museum of Natural History, number 26.

Sohn, I.G. 1956. Pliocene ostracods from Jackson Hole. Wyoming Geological Association Guidebook 11th Annual Field Conference:120122. 